\title{
Article
}

\section{The Role and Importance of a Footbridge Suspended over a Highway in the Opinion of Its Users-Trabzon (Turkey)}

\author{
Maria Hełdak ${ }^{1, *}(\mathbb{D})$, Sultan Sevinc Kurt Konakoglu ${ }^{2}\left(\mathbb{D}\right.$, Banu Cicek Kurdoglu $\left.{ }^{3}{ }^{(}\right)$, Hande Goksal ${ }^{3}$, \\ Bogdan Przybyła ${ }^{4}$ and Jan K. Kazak ${ }^{1}$ (D) \\ 1 Institute of Spatial Management, Wrocław University of Environmental and Life Sciences, \\ ul. Grunwaldzka 55, 50-357 Wrocław, Poland; jan.kazak@upwr.edu.pl \\ 2 Department of Urban Design and Landscape Architecture, Amasya University, 05100 Amasya, Turkey; \\ sultansevinc.kurt@amasya.edu.tr \\ 3 Department of Landscape Architecture, Karadeniz Technical University, 61080 Trabzon, Turkey; \\ banukurdoglu@ktu.edu.tr (B.C.K.); hande.altug@hotmail.com (H.G.) \\ 4 Department of Mechanics of Structers and Urban Engineering, Wrocław University of Science and \\ Technology, 50-370 Wrocław, Poland; bogdan.przybyla@pwr.edu.pl \\ * Correspondence: maria.heldak@upwr.edu.pl
}

check for updates

Citation: Hełdak, M.; Kurt Konakoglu, S.S.; Kurdoglu, B.C.; Goksal, H.; Przybyła, B.; Kazak, J.K. The Role and Importance of a Footbridge Suspended over a Highway in the Opinion of Its Users-Trabzon (Turkey). Land 2021, 10, 340. https://doi.org/ 10.3390/land 10040340

Academic Editor: Iwona Cieślak

Received: 5 March 2021

Accepted: 22 March 2021

Published: 27 March 2021

Publisher's Note: MDPI stays neutral with regard to jurisdictional claims in published maps and institutional affiliations.

Copyright: (c) 2021 by the authors. Licensee MDPI, Basel, Switzerland. This article is an open access article distributed under the terms and conditions of the Creative Commons Attribution (CC BY) license (https:// creativecommons.org/licenses/by/ $4.0 /)$.

\begin{abstract}
In the urban landscape, footbridges appeared along with the development of urbanization through the implementation of more complex spatial structures. The introduction of transport transit to cities or sometimes urban gravity towards the important communication routes imposed their construction in order to ensure pedestrians' safety and smooth flow of traffic. The aim of the study is to determine how an overpass in the city of Trabzon is used by people of different ages, the security and motivation problem, the possibility of a footbridge, and how an overpass is perceived as a crossing over a highway. The study addresses the problem of safety and motivation related to the use of an overpass by people of different ages and is focused on the perception of an overpass as a crossing over a highway. The overpass connects the northern part of the city with the parking lot and the seaside boulevards in Trabzon. It has been constructed over the road no. D010, also known as the Black Sea Coastal Highway. In total, 124 members of the urban population who used the overpass participated in a questionnaire, which included multiple-choice and open-ended questions. The 'Semantic Differential Scale' was also used to evaluate the results. The research revealed that the respondents who chose the road through the overpass for safety in most cases used it relatively rarely (59\%). People who used the footbridge every day or frequently marked safety as the reason in $39 \%$ of cases only. This means that as pedestrians use the overpass more often, they begin to notice other functional features of the footbridge. The results of the study showed that the overpass was most frequently used for the purpose of going down to the coast $(76.0 \%)$, although $51.2 \%$ reported rarely using the overpass, which showed it was used very little by pedestrians.
\end{abstract}

Keywords: footbridge; urbanization; functions of pedestrian bridges; Trabzon

\section{Introduction}

An urban space as a whole consists of structures and open areas where all urban activities are perceived by the inhabitants of the city. In other words, these spaces are where the activities in the lives of the urban dwellers take place. They include places for housing, working, entertainment, transportation and recreation [1].

According to Hasan and Napiah [2], for centuries, people have tried to walk over environments that contained a variety of terrains such as mountains, hills, valleys and rivers. With the advancement of civilization and urbanization of cities, which resulted in more complexes and civilized environments of habitation, and also with the development of cities having more complex communication systems, attempts were made to solve the problem of pedestrians' safety. 
A footbridge was one of the objects that appeared in space along with the development of urbanization. The reason for implementing this type of solution was, firstly, ensuring the safety of pedestrians and, secondly, maintaining uninterrupted vehicle traffic. Therefore, the contemporary definition of a footbridge indicates that it is a vertical separation device used to separate pedestrians from road traffic without risking an accident [3].

Urban inhabitants must use urban spaces in all aspects of their lives. However, only the presence of appropriate and adequate technical, functional, aesthetic and behavioral reinforcement elements can enable people to use urban spaces in the best possible way. Reinforcing elements not only meet the needs of the people but also have psychological effects on them [4].

The most active forms of transportation are walking and bicycling, which have the lowest impact on the environment and improve the physical health of pedestrians and bicyclists. The most common problem impeding the preference for walking and bicycling is traffic safety [5-7].

Pedestrians are most at risk when they are crossing the road. This represents a significant proportion of all fatalities among pedestrians, amounting to $50 \%$ in non-built-up areas and $75 \%$ in built-up areas. The most frequent reason for this kind of accident is failure to give way $[8,9]$.

Pedestrians who are crossing are considered to be one source of congestion [10]. According to Binti Kadzim, a pedestrian bridge is the best solution for pedestrians to cross the road. A pedestrian bridge is only one way to increase road network capacity [11].

Bridges connect destinations in communities and provide access to emergency and essential services. Bridges that lack pedestrian and bicycle accommodations can force substantial detours or sever routes entirely, discouraging or eliminating the option to walk and bike for transportation. Those who do travel on bridges without proper accommodations may increase their risk of being involved in a crash [12,13].

Pedestrian and bicycle bridges will provide that pedestrian and bicycle users can cross the road safely and go to school or businesses safely. Therefore, where it is needed, the design and the material used in the design are very important. Pedestrian and bicycle bridges should be both "functional" and "aesthetic" [14].

In both urban and landscape design studies, there is a need for a variety of structural elements that meet the physical needs of the population and are necessary for their understanding, safety and comfort in terms of health and a clean environment. These elements are defined as urban elements, and they should be compatible with other elements and improve the visual quality of the landscape design as a whole when used correctly [15]. Among these elements are pedestrian overpasses that provide pedestrian access, i.e., pedestrian bridges. These overpasses or bridges have the especially important goal of providing pedestrians with a means to travel within or between the areas that we call urban spaces. Although the main purpose of pedestrian bridges is to facilitate transport and increase pedestrian safety, this function alone is not enough for users. Bridges must also have an aesthetic value. They should also accommodate different types of activities for pedestrians. This condition determines the value of an urban pedestrian bridge [16-19].

Tunnels and pedestrian bridges should be used as collision-free crossings when [20] pedestrian routes intersect with higher class roads, pedestrian routes intersect with the roads of G (main road) or GP (major trunk road) class with heavy traffic, and the location of an at-grade pedestrian crossing may pose a serious hazard to pedestrians or cause long delays for vehicles and pedestrians.

According to studies conducted by Jamroz et al. [20], Ivan et al. [21], Congiu et al. [22] and Arroya et al. [23], most pedestrians and bicyclists were at risk of accidents. In today's cities, pedestrian zones are being implemented to provide comfortable and safe passage for pedestrians.

Pedestrian overpasses are structures that allow pedestrians to carry out their movements easily and conveniently. For this reason, some of them are built over vehicle traffic roads, some over parks and gardens and some over waterways. Their construction materi- 
als can be wood, stone, brick, reinforced concrete, steel or metal, and hybrid solutions are also used, in which the structural elements are made of different materials working together. They can be in the form of beam, arch, cantilever, suspension or truss bridges [24-28].

These structures pass over roads that are open to vehicle traffic and, in addition to their functional purpose of facilitating and directing the continuous flow of uninterrupted pedestrian movement and ensuring pedestrian safety, these passageways function as urban reinforcement elements that, with their aesthetic aspects, can affect the city's appearance. Therefore, the design criteria used for features and fixtures in urban spaces should also be applied to pedestrian overpasses.

Various examples of functional solutions for pedestrian bridges over roads can be listed as well as the attempts of classifying such constructions can be taken up considering their secondary function - apart from the basic one, i.e., ensuring safety for pedestrian, pedestrians and cycling traffic in cities, or providing the possibility of reaching dangerous and attractive landscape spots located in open spaces. In the urbanized area (city) the following can be identified:

- pedestrian bridges over roads and among them very spectacular solutions such as, e.g., "Ponte Segunda Circular Bridge" in Portugal, the "BP Pedestrian Bridge" in Chicago (USA), the "Lunchtsingel Bridge" in Holland;

- $\quad$ pedestrian bridges with water elements and over wetlands, e.g., the "Media City Footbridge' in England, the "Cirkelbroen Bridge" in Denmark, the "Iceland Bicycle Bridge" in Iceland, the "Golden Garland Bridge" and "Melkweg Bridge" in Holland and the "Merchant Square Footbridge" and "Millennium Bridge" in London.

The efforts aimed at revitalizing railway bridges and road viaducts into overpasses can be noticed both in cities and in open areas. The examples of using constructions that previously performed different functions and created by conversion of remnants are the "Promenade Plantee" in Paris and in the USA the "High Line Park", "Walkway Over the Hudson" in New York, the "Kinzua Bridge State Park" in Pennsylvania and the "Vance Creek Bridge" in Washington State.

The overpasses built in open areas are often examples of architecturally outstanding constructions, harmoniously integrated into the natural landscape. They frequently constitute impressive structures offering complex architectural solutions, e.g., the "High Trestle Trail Bridge" in Madrid, the "Moses Bridge" in Holland, the "Plitvice Lakes National Park Bridge" in Croatia, the "Zhangjijie Grand Canyon Glass Bridge" in China, the "Langkawi Sky Bridge" in Malaysia, the "Jasper National Park Glacier Skywalk" in Canada and the "Tree Top Walkway" in London.

Pedestrian bridges, especially in heavy traffic areas, were designed as a solution in the context of pedestrian safety and the continuity of the roadways. In addition to being designed engineering structures, their aesthetic aspects can be evaluated as elements of significant urban fixtures. Pedestrian overpasses are important elements that should be considered not only for their functional requirements, but also as elements that can affect the city image and aesthetics. Consequently, pedestrian bridges can be regarded as being important to the city as creative elements that can attract attention due to their larger scale $[29,30]$. It is worth noting two approaches in the architectural shaping of footbridges (and bridges in general), this first aiming at creating a characteristic element, recognizable and noticeable even from a distance, and the second assuming the maximum integration (concealment) of a new object in the landscape [16,18,31].

The authors of the presented research focused on the problem of safety and motivation for using an overpass by people representing different age groups and on the perception of a footbridge as a crossing over a highway.

The authors noticed that the residents of Turkish cities are reluctant to use overpasses, which results in numerous problems related to road safety (in the case of an overpass construction, traffic lights and pedestrian crossing are not located in the same place, i.e., "a zebra crossing" through the road). There is evidence that some types of facilities are 
generally disliked by pedestrians, which leads to a high incidence of informal road crossing behavior, away from crossing facilities [32-35].

The research addressing footbridges is focused on

- $\quad$ ensuring safety in crossing roads and passing over other obstacles in pedestrian traffic [10-13,20-23,32-35];

- technology, building materials and durability of the constructed footbridges [24,28],

- $\quad$ user comfort (vibration frequency) [36-40];

- $\quad$ adapting architectural form and structure to the surrounding space [16-19,29-31].

There is a gap in analyzing opinions on the multifunctionality of buildings over highways in cities in terms of assessing a viaduct in the category of an aesthetic, functional and identity type of element, which was the basis for the conducted research. However, the primary function of a footbridge (ensuring safety) cannot be neglected, which constitutes the background of the conducted research.

The following research hypotheses were put forward in the article:

Hypothesis 1 (H1). Young people and students of different age groups Trabzon residents are more likely to use overpass than older and working people.

Hypothesis 2 (H2). Young people pay attention to the advantages of a footbridge other than safety.

Hypothesis 3 (H3). The awareness of ensuring safety and motivation for oneself and family grows with age.

The purpose of the research was to show the preferences of Trabzon residents and visitors in terms of using the overpass built over the highway. The overpass connects the northern part of the city with the parking lot and the seaside boulevards in Trabzon. It has been constructed over the road no. D010, also known as the Black Sea Coastal Highway. This road is the main west-east highway in Turkey, serving the Black Sea Coast. In this part of the city, the road is a barrier to access the Black Sea shore. On the one hand, the city's spatial development and the density of buildings and, on the other hand, the significant traffic of motor vehicles resulted in the need to search for solutions in the form of safe access to coastal boulevards. There are seven footbridges along the section of the route running through the city of Trabzon, whereas only a small part of the road runs through an underground tunnel. The importance of this study is to reveal the design, safety, comfort, aesthetics, symbolic element and importance for transportation of an overpass in Trabzon city.

\section{Materials and Methods}

The Imperial Overpass, which is located within the boundaries of Ortahisar district of Trabzon city, where area field studies were carried out in the study, constitutes the main material of the study. Observations and questionnaire studies, photographs taken during field studies, SPSS 16.0 statistical program were other materials used in the research.

Imperial Overpass, which connects Gazipasa Street in the city center of Trabzon to the Black Sea Coastal Highway, has been chosen as the study area (Figure 1). The Black Sea Coastal Highway is the main west-east highway in Turkey, serving the Black Sea Coast. The reasons for choosing Imperial Overpass are as follows: it is very close to the city center of Trabzon, it is used intensively by pedestrians, there are bus stops that provide transportation to Trabzon city with other districts, it connects the city center with the coastal area and it provides access to the parking lot of the Imperial Hospital. 


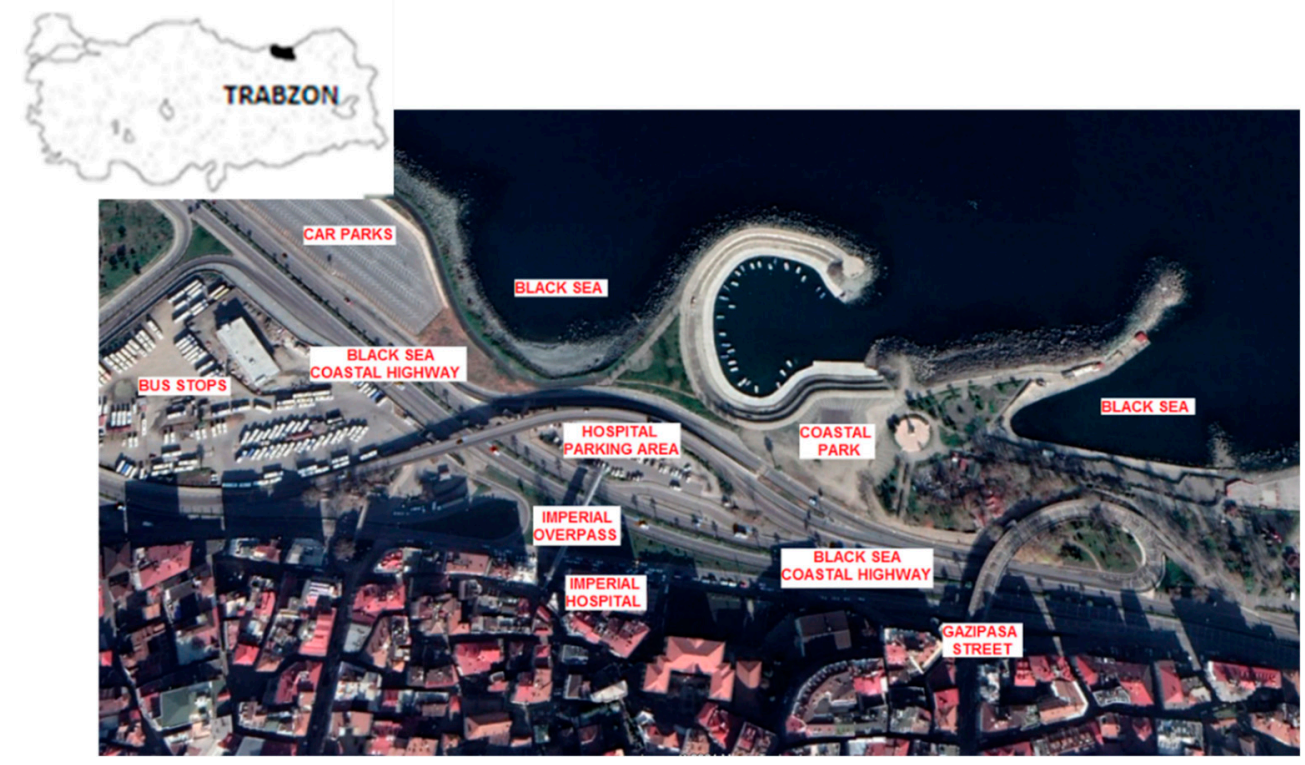

Figure 1. Satellite image showing the study area. Source: own study.

Steel was used in the construction of the footbridge, and the floor is of cast concrete. One abutment is located over a section of road in a residential area, while the other is connected to the hospital parking area (Figures 2 and 3).

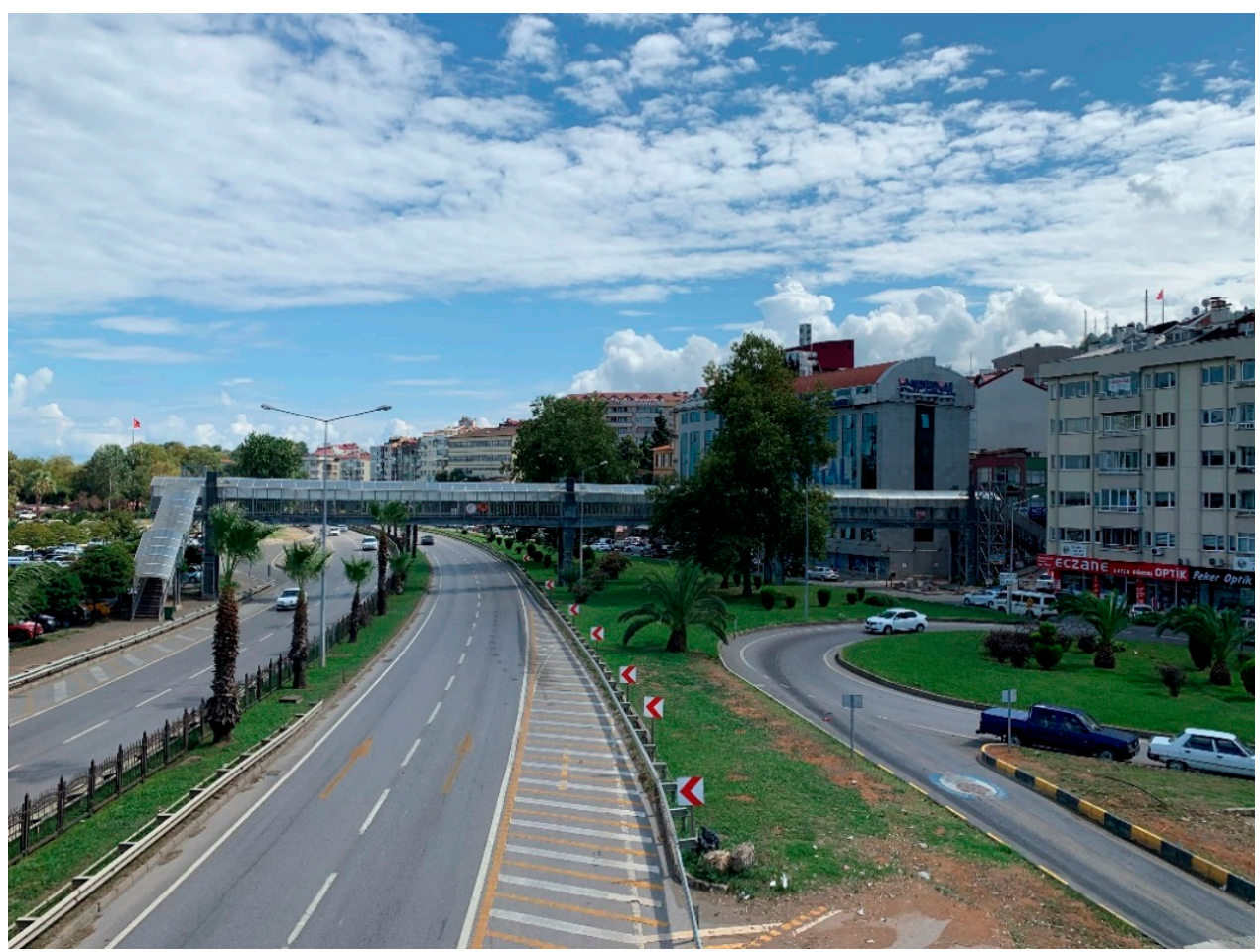

Figure 2. The view of the overpass over the road no. D010, also known as the Black Sea Coastal Highway, after construction of the roofing. Source: own study. 


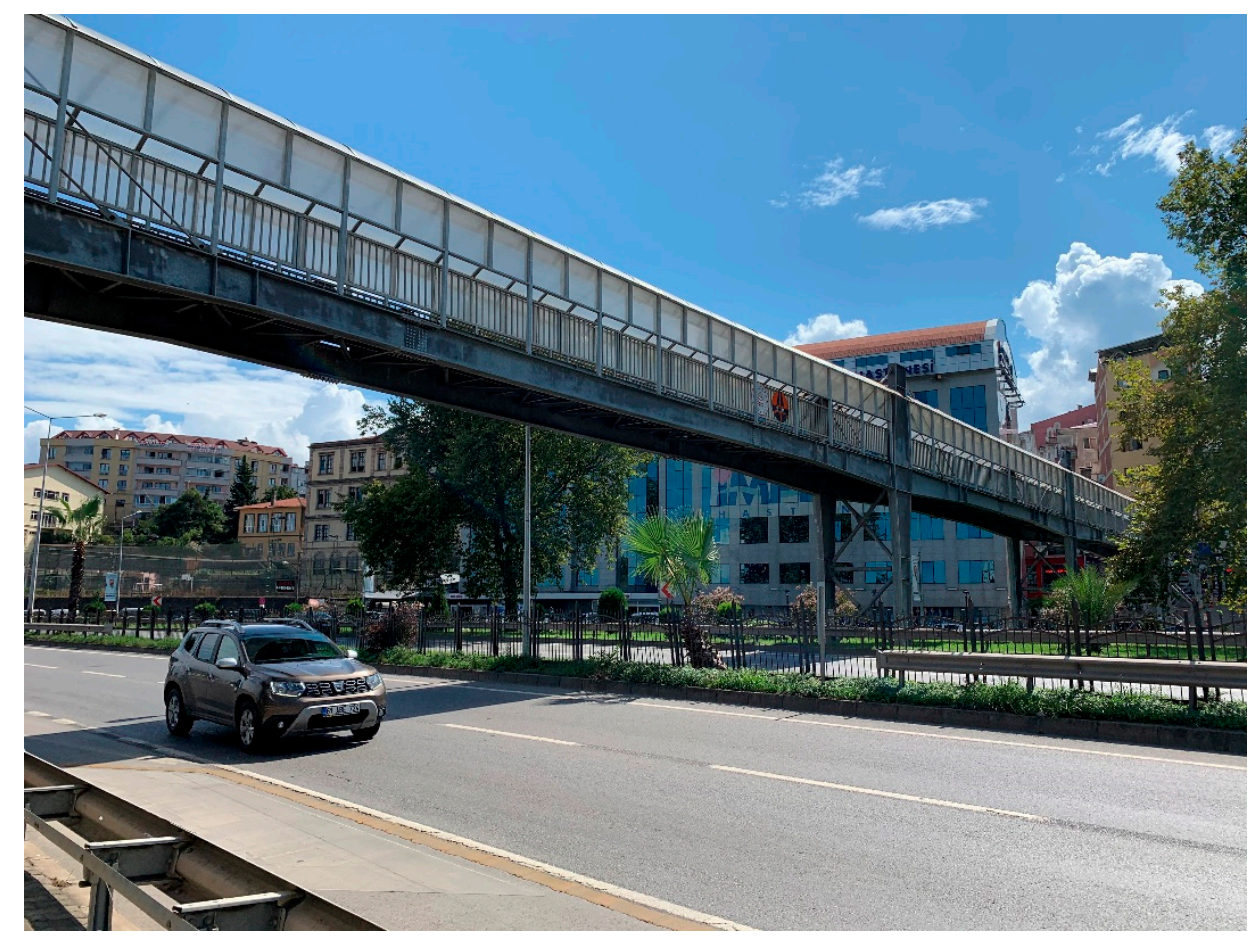

Figure 3. The view of the overpass over the road no. D010, also known as the Black Sea Coastal Highway, after construction of the roofing. Source: own study.

The presented research was carried out according to the following research scheme:

1. The identification of the research problem, the selection of the research area and the formulation of the research purpose and the research questions;

2. Collecting information and developing database for the analyzed footbridge,

3. Developing a questionnaire (survey) and conducting a survey in the area of Trabzon (Turkey);

4. Analyzing findings using the descriptive method and statistical methods and seeking correlations;

5. Valuation of preferences and expectations using the Semantic Differential Scale.

6. Verification of the research hypotheses, discussion and conclusion.

Some of the issues concerning the footbridge include:

- Technical problems: These include spills on the bridge caused by the steel material, paint problems, lack of binding materials and damage caused by the users, as well as whether the bridge is not convenient for everyone to use.

- Aesthetic problems: There were no design criteria for the bridge that could add value to the space. It is simply an overpass made of a steel carriers and concrete labs.

Taking into account the overpass location along the frequently used pedestrian route and also in an important cultural and landscape place, i.e., in the center of Trabzon city, the research was carried out to identify the expectations and motives of those using the aforementioned footbridge over the road. The popular and busy communication route (highway no. D010) definitely cut off the coast and seaside boulevards from the city, and the overpass under study allows reaching these places without collisions. However, does it meet the residents' expectations? Does its form correspond to the significance of the space in which it is located? In order to obtain answers to a number of doubts and to find out the preferences of the overpass users, the following research questions were formulated: 
- Are young people more likely to use the overpass than older and working people?

- Is the crossing over the highway considered safe for all users of the overpass?

- Does the awareness of ensuring safety for oneself and family grow with age?

- How do users rate the overpass in the categories of aesthetic, functional and identityoriented elements?

In the study, the quantitative research (questionnaire) method was applied to inhabitants of Trabzon in order to determine the current usage status of the Imperial Overpass and to determine the feasibility of pedestrian and bicycle bridges in the city. For the study, a questionnaire-based field survey was administered and face-to-face interviews were carried out to determine the reasons the people of Trabzon city used the overpass and how frequently they visited it (Supplementary Material). The purpose of the quantitative research method was to qualify the numerical information. Before the questionnaire questions were prepared, on-site observations were made by going to the study area. The studies of Arslan Selcuk and Er Akan [1], Hasan and Napiah [2], Kuşkun [4], Mumcu [41] and Denli [42] were consulted during the preparation of the questionnaire. The urban population of 2019 was taken into account when determining the number of people to be surveyed. According to the data obtained from Turkish Statistical Institute, the population of Trabzon Central District in 2019 was 328,457. During the preparation of the questionnaire, care was taken to ask clear and understandable questions that could be answered, while still respecting people's privacy. The questionnaires were designed for individuals over the age of 18 , with the idea that they would take a more conscientious approach. The questionnaire was carried out between March and August 2019, with 124 people living in the city center of Trabzon. The random sampling method was used to determine the sampling size for the questionnaire study. The inhabitants who participated in the questionnaire were asked a total of 12 multiple-choice questions and also provided information about their demographic characteristics. Each questionnaire took an average of $20 \mathrm{~min}$.

The results of the demographic composition of the 124 people who participated in the survey were as follows:

Gender: 78 (60.5\%) were female and $46(35.7 \%)$ male.

Age: $45(34.9 \%)$ were aged $18-23$ years, $49(38.0 \%)$ were aged $24-29$ years and 30 $(23.3 \%)$ were aged $30+$ years. The average age of the respondents was 28.0 years of age, with a standard deviation of 9.85 years. At least half of the respondents were not older than 25. The youngest respondent was 18 years old, whereas the oldest one 63 .

Educational status: $4(3.1 \%)$ had completed primary school, $1(0.8 \%)$ middle school, $18(14.0 \%)$ high school, $84(65.1 \%)$ university and $17(13.2 \%)$ post-graduate education.

Occupational status: $27(20.9 \%)$ were architects/engineers, 50 (38.8\%) were students, and $47(36.4 \%)$ were in other occupations.

The survey was conducted with the participation of 124 individuals, of whom 50 were randomly selected, 27 were architects/engineers and 47 were from other professions. In addition, in order to determine the value of the overpass in terms of semantic aspects, the contexts of using the overpass other than their preferences and expectations were detected in accordance with adjective pairs using the Semantic Differential Scale. In this respect, the participants were asked to evaluate the overpass using the adjectives "functional", "harmonious", "aesthetic", "attractive", "special", "memorable" and "safe" and their paired counterparts using a 7-point scale. The scale given in Table 1 below was used for scoring. The participants were people living in Trabzon who used the overpass. Therefore, assessments were facilitated by reminder photographs used during the survey (Figure 4). The data were analyzed using the SPSS 16.0 statistical program. In the study, correlation analysis was performed with descriptive statistics. 
Table 1. Evaluation system of the criteria used in the survey.

\begin{tabular}{ccccccccc}
\hline \multirow{2}{*}{ Criteria } & \multicolumn{7}{c}{ Intensity of the scale: } & \multirow{2}{*}{ Criteria } \\
\cline { 2 - 7 } & $\mathbf{1}$ & $\mathbf{2}$ & $\mathbf{3}$ & $\mathbf{4}$ & $\mathbf{5}$ & $\mathbf{6}$ & $\mathbf{7}$ & \\
\hline Dysfunctional & 1 & 2 & 3 & 4 & 5 & 6 & 7 & Functional \\
Irregular & 1 & 2 & 3 & 4 & 5 & 6 & 7 & Regular \\
Not aesthetic & 1 & 2 & 3 & 4 & 5 & 6 & 7 & Aesthetic \\
Not attractive & 1 & 2 & 3 & 4 & 5 & 6 & 7 & Attractive \\
Ordinary & 1 & 2 & 3 & 4 & 5 & 6 & 7 & Private \\
Forgettable & 1 & 2 & 3 & 4 & 5 & 6 & 7 & Unforgettable \\
Insecure & 1 & 2 & 3 & 4 & 5 & 6 & 7 & Secure \\
\hline
\end{tabular}

1: dysfunctional; 2: somewhat dysfunctional; 3: minimally dysfunctional, 4: average; 5 : minimally functional; 6 : somewhat functional; 7 : functional. Source: own study.

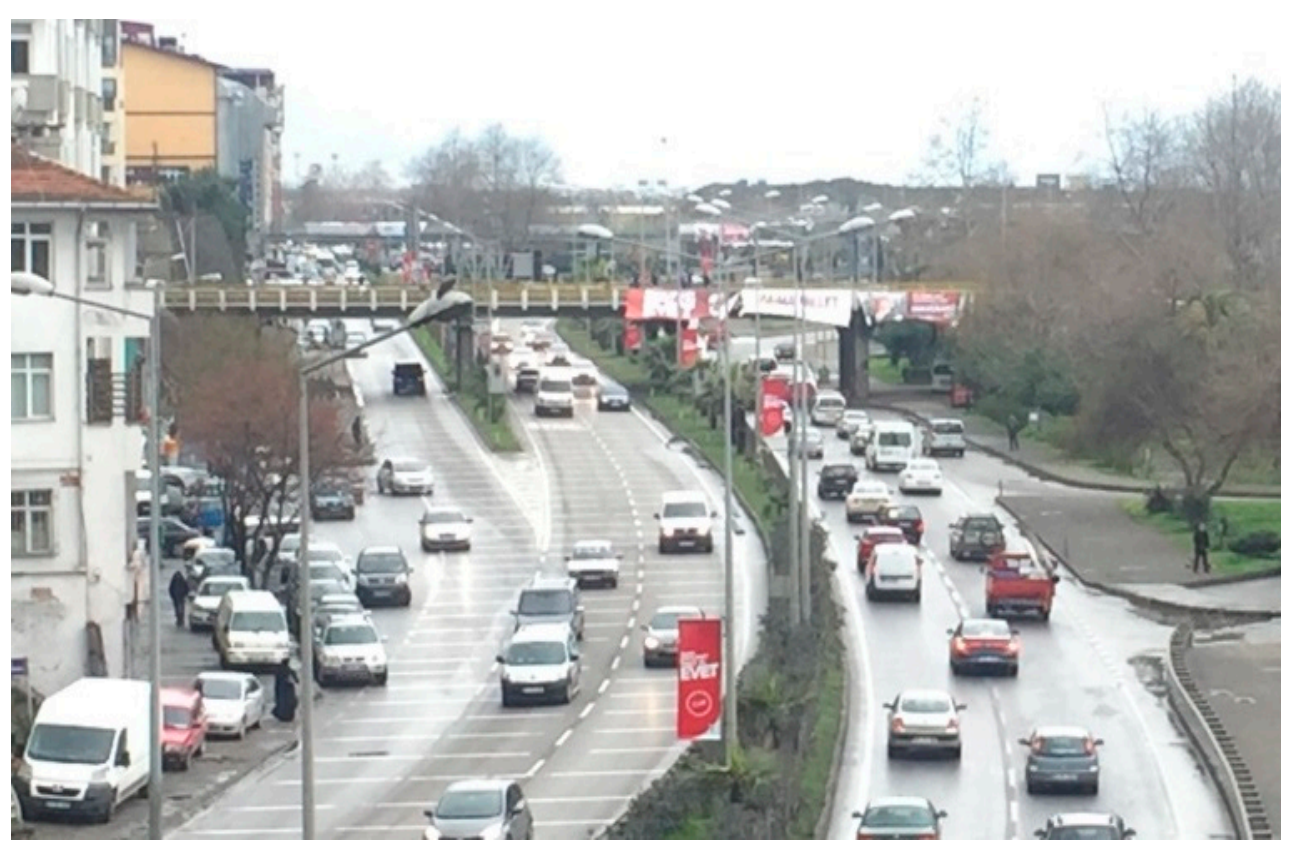

Figure 4. Photographs used in the survey.

The significance of differences in the distribution of responses between nominal variables was checked using the chi square test of independence. To calculate the chisquare statistics, the following formula was used:

$$
\chi^{2}=\sum_{i=1}^{n} \frac{\left(O_{i}-E_{i}\right)^{2}}{E_{i}}
$$

where:

$\mathrm{O}-$ Observed value;

E-Expected value.

For all analyses, the maximum permissible error class I $\alpha=0.05$ was adopted, and $p \leq 0.05$ was considered statistically significant.

\section{Results and Discussion}

Beyond any doubt, the Black Sea route remains in conflict with the development of the city tourist function. Urbanization processes resulted in the need to search for solutions allowing the separation of pedestrians and vehicle traffic. Unfortunately, the analyzed object differs from the contemporary design solutions, which often fit into the surrounding landscape, and their implementation uses modern engineering techniques and construction 
materials. Frequently, such objects make the landscape more attractive, which cannot be said about the analyzed footbridge.

When asked about the frequency of using the overpass, out of the total of 124 people, $51.2 \%$ answered "Rarely", 14.0\% "1-2 times per month", 10.1\% "Everyday" and "Frequently", $7.0 \%$ "1-2 times per week", 3.9\% "2-3 times per week".

The overpass does not connect university buildings or any other buildings used primarily by people under 25 , it is generally accessible and apart from the car park and it also provides access to the seaside boulevards. Hence, it was reasonable to analyze who the main users of the overpass are and how frequently they use it.

Correlation analysis using Spearman's rank correlation coefficient confirmed a statistically significant relationship between age and the frequency of using overpass $(p=0.005)$; however, this relationship was different from that formulated in the hypothesis. Older respondents used overpass more frequently; therefore, the discussed hypothesis should be rejected (Table 2).

Table 2. The values of Spearman's rank correlation coefficient. The relationship between age and the frequency of using overpass.

\begin{tabular}{cc}
\hline Statistical Measures & Frequency of Use \\
\hline Correlation Coefficient & 0.25 \\
Sig. (2-tailed) & 0.005 \\
\hline
\end{tabular}

Source: own study.

A statistical analysis was also carried out using the chi square test of independence. To this end, the respondents were divided into two groups, where the division point was the median value for the age variable ( 25 years of age). Some categories related to frequencies of using overpass were also combined, so that the smallest percentage of cells in the developed cross-table had an expected number of less than 5 . The respondents under 25 years of age rarely used the overpass $(64 \%)$, and the percentage of such population aged over 25 was smaller and amounted to $40 \%$. The percentage of people using the overpass often and daily in the group under or at the age of 25 was $12 \%$, whereas among older people it was $32 \%$. The differences are statistically significant $(p=0.027)$ (Table 3 ).

Table 3. The distribution of responses broken down by age.

\begin{tabular}{cccc}
\hline \multirow{2}{*}{ Frequency of Using } & Score & \multicolumn{2}{c}{ Age: } \\
\cline { 3 - 4 } & & $\leq \mathbf{2 5}$ Years & $>\mathbf{2 5}$ Years \\
\hline \multirow{2}{*}{ Rarely } & Count & 43 & 23 \\
& \% within Age & $64.2 \%$ & $40.4 \%$ \\
\hline \multirow{2}{*}{$1-2$ times per month } & Count & 9 & 9 \\
& \% within Age & $13.4 \%$ & $15.8 \%$ \\
\hline \multirow{2}{*}{ Few times per week } & Count & 7 & 7 \\
\hline \multirow{2}{*}{ Frequently or every day } & \% within Age & $10.4 \%$ & $12.3 \%$ \\
\hline \multicolumn{2}{c}{ Pearson Chi-Square } & 8 & $31.6 \%$ \\
\hline \multicolumn{2}{c}{ Count } & $11.9 \%$ & $\chi^{2}=9.16 ;$ Sig. $=0.027$ \\
\hline
\end{tabular}

The statistical analysis using the chi square test of independence showed a statistically significant relationship between social status and the frequency of using the overpass $(p=0.018)$. The answer often or daily was indicated by $7 \%$ of the respondents from the group of engineers, $16 \%$ by students, most often by other respondents- $34 \%$ (Table 4 ). 
Table 4. The distribution of responses broken down by social status.

\begin{tabular}{|c|c|c|c|c|}
\hline \multirow{2}{*}{ Frequency of Use } & \multirow{2}{*}{ Score } & \multicolumn{3}{|c|}{ Social Status (Job): } \\
\hline & & Engineer-Architect & Student & Other \\
\hline \multirow{2}{*}{ Rarely } & Count & 12 & 31 & 23 \\
\hline & $\%$ within Social status & $44.4 \%$ & $62.0 \%$ & $48.9 \%$ \\
\hline \multirow{2}{*}{ 1-2 times per month } & Count & 8 & 6 & 4 \\
\hline & $\%$ within Social status & $29.6 \%$ & $12.0 \%$ & $8.5 \%$ \\
\hline \multirow{2}{*}{ Fewtimes per week } & Count & 5 & 5 & 4 \\
\hline & $\%$ within Social status & $18.5 \%$ & $10.0 \%$ & $8.5 \%$ \\
\hline \multirow{2}{*}{ Frequently or every day } & Count & 2 & 8 & 16 \\
\hline & $\%$ within Social status & $7.4 \%$ & $16.0 \%$ & $34.0 \%$ \\
\hline \multicolumn{2}{|c|}{ Pearson Chi-Square } & \multicolumn{3}{|c|}{$\chi^{2}=15.34 ;$ Sig. $=0.018$} \\
\hline
\end{tabular}

Source: own study.

When asked about the direction of moving through the overpass-in the first place, $76.0 \%$ of the respondents answered "To go to the coast", followed by $9.3 \%$ in second place with "To go to the city center", $7.8 \%$ in the third place with "To go home", 2.3\% "To go to the hospital" and, finally, $0.8 \%$ responded "To go to the university" (Figure 5).

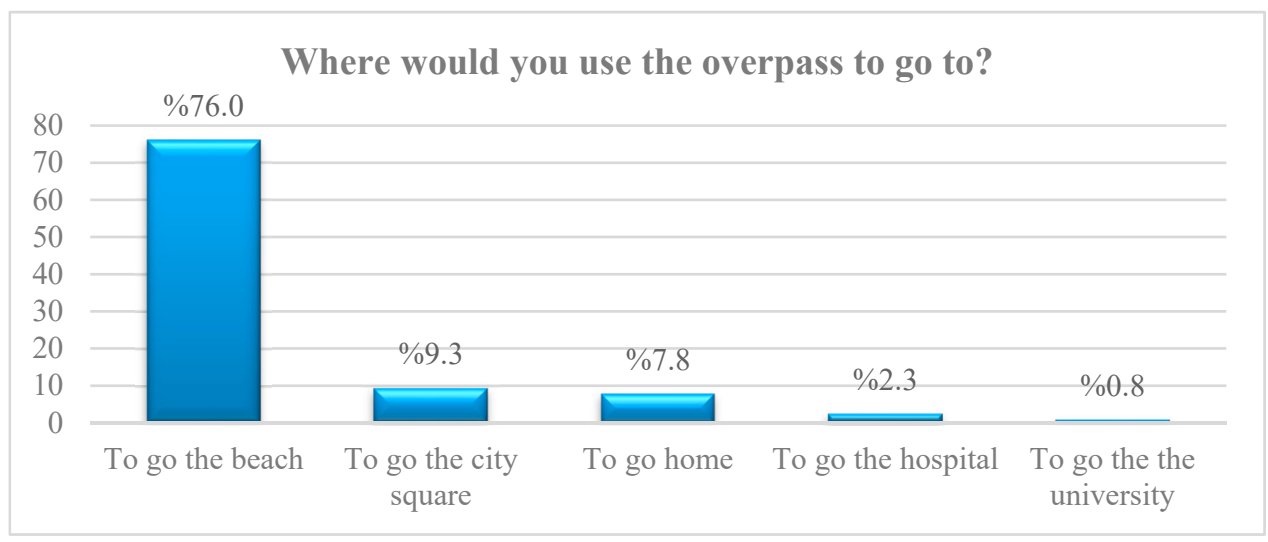

Figure 5. Reasons for overpass use.

The highway limits the possibility for taking advantage of using the coastal location of the city in many respects. First of all, by cutting off the coast and the seaside boulevards from the invested part of the city, it reduces opportunities for the development of recreation and tourism in such a large city of 240,000 residents.

As has been confirmed by the conducted research, the primary purpose of using the overpass is to ensure safety-out of the total number of 124 participants, $36.4 \%$ provided the answer "For security", 27.9\% "There is no alternative", 20.2\% "It's a convenient route", $10.1 \%$ "It's the way to the coast" and $1.6 \%$ "It's the way to the parking lot" (Figure 6).

Ensuring safety on the one hand and smooth traffic flow of motor vehicles on the other obviously remains the essential purpose of constructing overpasses. However, not all of the respondents indicated safety as the reason for choosing the discussed footbridge, other reasons were as follows: no alternative, convenience and the way to reach the destination (coast, parking lot). Indeed, the traffic of motor vehicles on the highway no. D010 is so intense that virtually all along its length in Trabzon, it is required to use either an overpass or an underpass to get to the other side. 


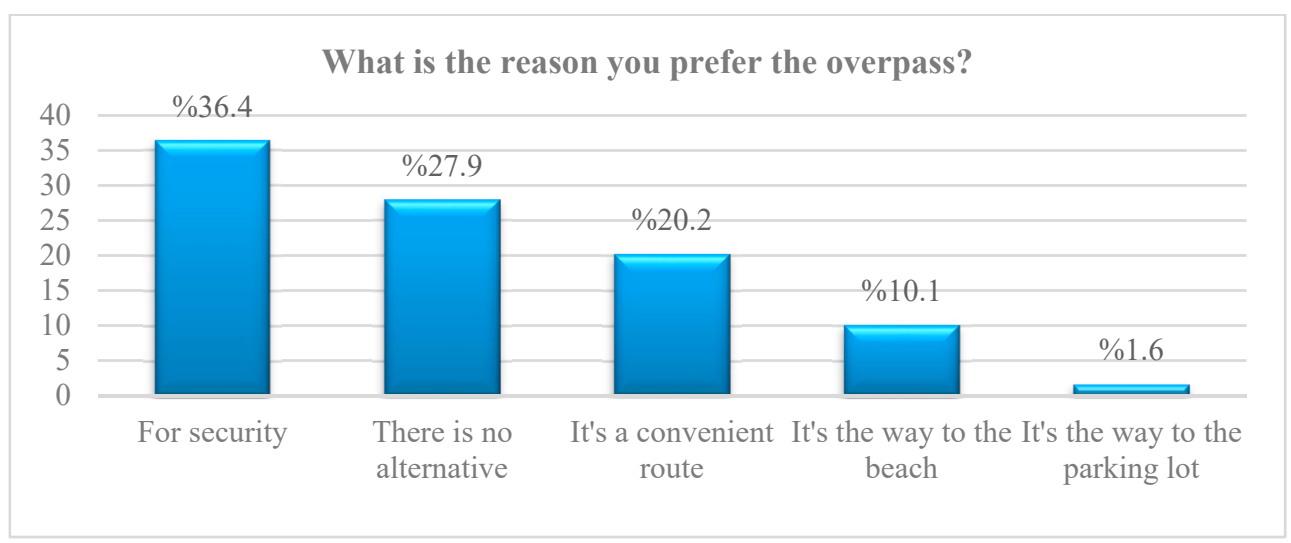

Figure 6. Reasons for preferring the overpass.

It is important that such a possibility of reaching the sea is also attractive for the pedestrians in every respect (apart from safety, the equally important factors are comfort, harmony with the surroundings and an attractive architectural form of the facility).

The respondents who chose the way through an overpass for safety reasons generally used it rarely (59\%), and the percentage of such people among those selecting an overpass for another reason was smaller and amounted to $31 \%$. Such individuals often used an overpass daily or often $(39 \%)$. The analysis using the chi square test of independence showed that the discussed differences are statistically significant $(p=0.019)$ (Table 5).

Table 5. Reasons for choosing vs. frequency of using an overpass.

\begin{tabular}{cccc}
\hline \multirow{2}{*}{ Frequency of Use } & Score & \multicolumn{2}{c}{ Reasons } \\
\cline { 3 - 4 } & & For Security & For Security \\
\hline \multirow{2}{*}{ Rarely } & Count & 58 & 8 \\
& \% within Reasons & $59.20 \%$ & $30.80 \%$ \\
\hline \multirow{2}{*}{$1-2$ times per month } & Count & 12 & 6 \\
Few times per week & \% within Reasons & $12.20 \%$ & $23.10 \%$ \\
\hline Frequently & Count & 12 & 2 \\
or every day & \% within Reasons & $12.20 \%$ & $7.70 \%$ \\
\hline Pearson Chi-Square & 16 & 10 \\
\hline & Source: own study. & $16.30 \%$ & $38.50 \%$ \\
\hline
\end{tabular}

The statistical analysis did not show any significant correlation between the respondent's age and the choice of safety as the reason for traveling through an overpass (Table 6).

Table 6. Reasons for the choice vs. age.

\begin{tabular}{cccc}
\hline \multirow{2}{*}{ Reasons } & Score & \multicolumn{2}{c}{ Age } \\
\cline { 3 - 4 } & & $\leq \mathbf{2 5}$ Years & $>\mathbf{2 5}$ Years \\
\hline \multirow{2}{*}{ For security } & Count & 54 & 44 \\
& \% within Age & $80.6 \%$ & $77.2 \%$ \\
\hline \multirow{2}{*}{ Other } & Count & 13 & 13 \\
& \% within Age & $19.4 \%$ & $22.8 \%$ \\
\hline \multicolumn{2}{c}{ Pearson Chi-Square } & \multicolumn{2}{c}{$\chi^{2}=0.22 ;$ Sig. $=0.643$}
\end{tabular}

Source: own study. 
The role of pedestrian bridges is not being fully implemented, because according to Abojaradeh, in Jordan, over $60 \%$ of pedestrians choose not to use pedestrian bridges for various reasons [36]. Females use them more than males and children more than adults. In that case, such a correlation was not confirmed.

The main advantage of pedestrian footbridges is that they separate pedestrians from road traffic. As a result, footbridges (and stopping pedestrians from crossing the roadway at-grade) may reduce pedestrian accidents up to $90 \%$ [8]. It was concluded that pedestrian bridges have a positive impact and have great potential to reduce the number of pedestrian fatalities [42]. When asked the question, "Do you consider the footbridge over the road no. D010 safe?", as many as 35.5\% of the respondents answered "No", however, their vast majority consider it safe (64.5\%) (Figure 7).

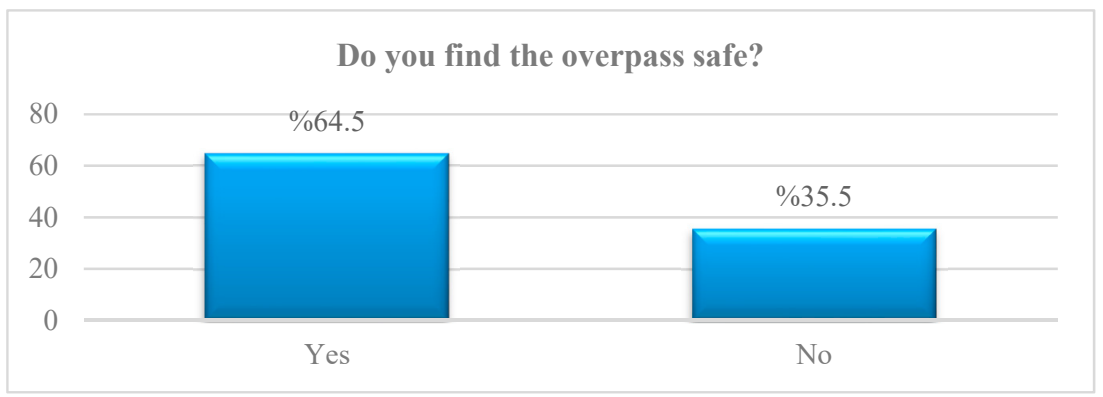

Figure 7. Reasons for preferring the overpass.

It is worth analyzing the reasons for the feeling of insecurity expressed by some of the people participating in the study. The preference for particular facilities also depends on their design and maintenance, which are associated with perceptions about crime and concerns about aesthetics and hygiene $[33,35,43,44]$. After performing the survey research, the overpass was covered with roofing, which definitely influenced the safety of using it (Figure 8). Unfortunately, the crossing is still not accessible, e.g., for people moving in wheelchairs, and causes many difficulties for those who have problems with mobility in general.

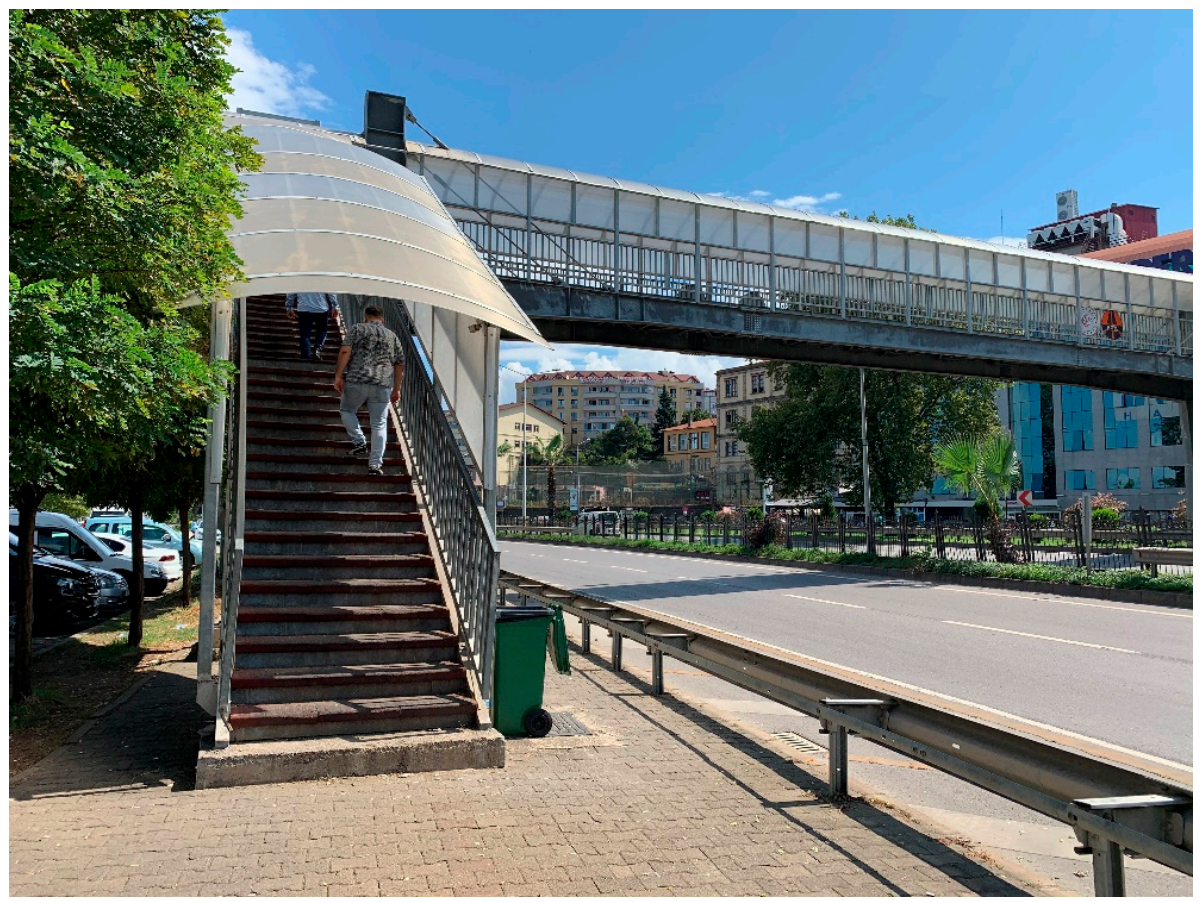

Figure 8. The overpass suspended over the highway no. D010 after constructing the roofing. 
Taking an overpass to cross the road may be perceived as attractive or not, and the footbridge itself, apart from ensuring a safe crossing over a communication artery, can also be used as a viewing point for walking, cycling or observing the surroundings. Building a pedestrian bridge over a highway allows for other activities. When asked, "How would you like to spend time in an area without vehicle traffic?", out of 124 participants, $34.9 \%$ responded "Walking", $24.0 \%$ "I do not know", 15.5\% "Riding a bicycle" and 10.9\% "Sitting/Observing/Having Fun" (Figure 9).

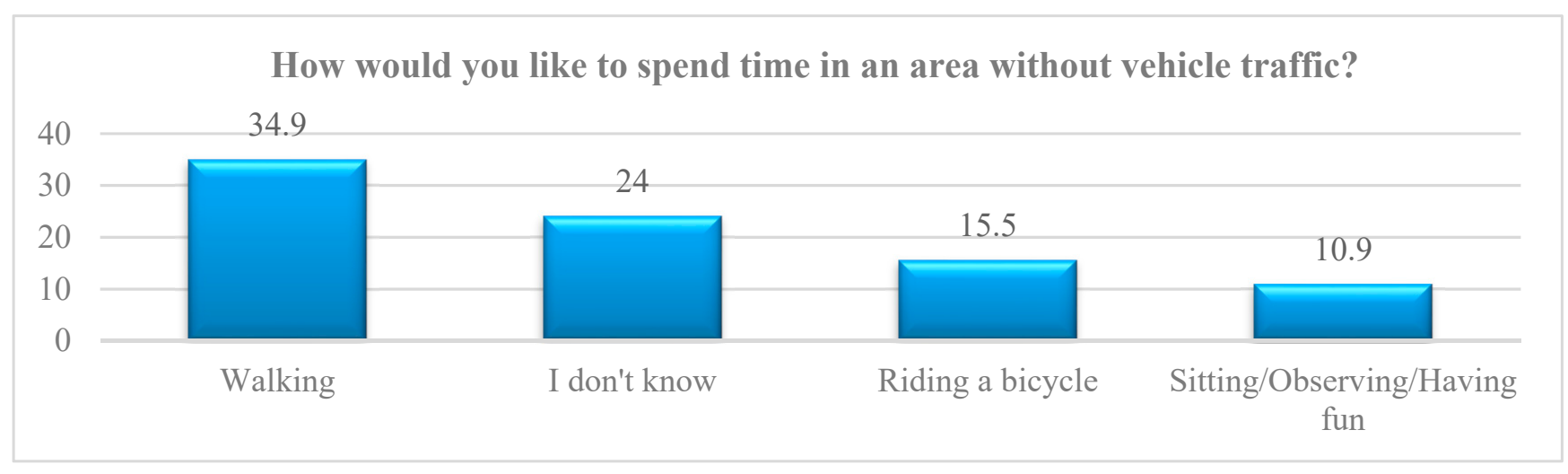

Figure 9. Activities that can be carried out on the overpass.

Taking into account the applied research methodology and the evaluation system of criteria used in the survey, presented in Table 1, the following research results were obtained. The average value of each criterion was calculated according to the results of the survey. In order to determine whether there is a relationship between the criteria, the average values given by the 124 people participating in the questionnaire for each criterion are averaged and summarized in Table 7.

Table 7. Average values of survey criteria.

\begin{tabular}{ccccc}
\hline Criteria & Min. & Max. & Average & Std. Deviation \\
\hline Functional & 1.00 & 7.00 & 5.3387 & 1.50277 \\
Regular & 1.00 & 7.00 & 4.1774 & 1.93827 \\
Aesthetic & 1.00 & 7.00 & 3.1532 & 1.69190 \\
Attractive & 1.00 & 7.00 & 3.2339 & 1.59322 \\
Private & 1.00 & 7.00 & 3.1774 & 1.62825 \\
Unforgettable & 1.00 & 7.00 & 3.6210 & 1.76503 \\
Secure & 1.00 & 7.00 & 4.3065 & 2.02094 \\
\hline
\end{tabular}

Source: own study.

The existence of a relationship among the criteria of "functional", "harmonious", "aesthetic", "attractive", "special", "memorable", and "safe" was assessed by applying the Spearman correlation test. According to the Spearman correlation, a significant positive correlation was found among all the criteria $(p<0.01)$. Among the criteria, the highest correlation coefficient values were found for "functional" with "harmonious", "harmonious" with "aesthetic", "harmonious" with "safe", "aesthetic" with "attractive", "attractive" with "special" and "special" with "memorable" (Table 8). The expected result was that all the criteria were interdependent because they all supported each other. 
Table 8. Relationship values among the criteria.

\begin{tabular}{ccccccccc}
\hline \multirow{2}{*}{ Relationship Criteria } & Functional & Regular & Aesthetic & Attractive & Private & Unforgettable & Secure \\
\hline \multirow{2}{*}{ Functional } & Cor. coe. & 1.000 & $0.569^{\prime \prime}$ & $0.457^{\prime \prime}$ & $0.403^{\prime \prime}$ & $0.279^{\prime \prime}$ & $0.303^{\prime \prime}$ & $0.550^{\prime \prime}$ \\
& Sig. level & - & 0.000 & 0.000 & 0.000 & 0.000 & 0.000 & 0.000 \\
\hline \multirow{2}{*}{ Regular } & Cor.coe. & $0.569^{\prime \prime}$ & 1.000 & $0.613^{\prime \prime}$ & $0.502^{\prime \prime}$ & $0.447^{\prime \prime}$ & $0.324^{\prime \prime}$ & $0.574^{\prime \prime}$ \\
& Sig. level & 0.000 & - & 0.000 & 0.000 & 0.000 & 0.000 & 0.000 \\
& Cor.coe. & $0.457^{\prime \prime}$ & $0.613^{\prime \prime}$ & 1.000 & $0.825^{\prime \prime}$ & $0.633^{\prime \prime}$ & $0.573^{\prime \prime}$ & $0.522^{\prime \prime}$ \\
\multirow{2}{*}{ Aesthetic } & Sig. level & 0.000 & 0.000 & - & 0.000 & 0.000 & 0.000 & 0.000 \\
\hline \multirow{2}{*}{ Attractive } & Cor. coe. & $0.403^{\prime \prime}$ & $0.502^{\prime \prime}$ & $0.825^{\prime \prime}$ & 1.000 & $0.670^{\prime \prime}$ & $0.576^{\prime \prime}$ & $0.503^{\prime \prime}$ \\
& Sig. level & 0.000 & 0.000 & 0.000 & - & 0.000 & 0.000 & 0.000 \\
\hline \multirow{2}{*}{ Private } & Cor. coe. & $0.279^{\prime \prime}$ & $0.447^{\prime \prime}$ & $0.633^{\prime \prime}$ & $0.670^{\prime \prime}$ & 1.000 & $0.721^{\prime \prime}$ & $0.424^{\prime \prime}$ \\
& Sig. level & 0.000 & 0.000 & 0.000 & 0.000 & - & 0.000 & 0.000 \\
\hline \multirow{2}{*}{ Unforgettable } & Cor.coe. & $0.303^{\prime \prime}$ & $0.324^{\prime \prime}$ & $0.573^{\prime \prime}$ & $0.576^{\prime \prime}$ & 0.721 & 1.000 & $0.464^{\prime \prime}$ \\
& Sig. level & 0.000 & 0.000 & 0.000 & 0.000 & 0.000 & - & 0.000 \\
\hline \multirow{2}{*}{ Secure } & Cor.coe. & $0.550^{\prime \prime}$ & $0.574^{\prime \prime}$ & $0.522^{\prime \prime}$ & $0.503^{\prime \prime}$ & $0.424^{\prime \prime}$ & $0.464^{\prime \prime}$ & 1.000 \\
& Sig. level & 0.000 & 0.000 & 0.000 & 0.000 & 0.000 & 0.000
\end{tabular}

Sig. level: Significance level; Cor. Coe.: Correlation coefficient; Source: own study.

The results of this study have emphasized that this overpass could carry a semantic and symbolic element in addition to the binding element. In parallel with the positive examples abroad, the overpass should be re-evaluated within a correct concept, format and scenario for its environment.

The positive adjectives that we used are a powerful semantic, syntactic and pragmatic fiction for the continuing research that needs to be done towards an overpass that can serve as an aesthetic, functional and identity element. The overpass that is the subject of this study must be recreated and, by using a correct design approach, a new pedestrian bridge with an identity must be generated. From a study of pedestrian bridge crossing conducted in Bangladesh (Dhaka), it was found that $71 \%$ of pedestrians prefer an underpass rather than using foot over bridge. Research conducted in Poland also confirmed a greater tendency to use underpasses by pedestrians compared to footbridges [9]. Always, however, one should take into account local conditions, which impose the only correct solution (in the presented case, the topography is decisive). The reasons pedestrians do not use road crossing facilities are insufficient security, the fact that they are time-consuming, poor entrances, hawker's problem, discomfort, the long walk required, etc. [10].

First of all, a good spatial composition should be prepared, and spatial components and items should be brought together in a harmonious way [41]. The composition of this architecture is formed by bringing the elements together and deliberately arranging them to create a semantically, functionally and visually satisfactory whole [45].

The space composition can be defined by the following semiotics to design a balanced pedestrian bridge. These;

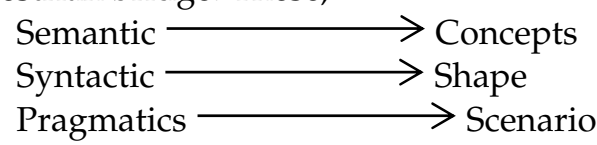

In order to design a balanced pedestrian bridge, the spatial composition can be defined by following the semantics. Semantics is actually the science of meaning [30]. When we consider it in a project, this term shows the semantic value, i.e., the concept, of the resulting design. In a way, it contains the main idea of the project. A concept is determined in the context of the semantic fiction, and the project is shaped by it.

Syntactic fiction contains a sense of meaning [46]. We can think of this form of syntax in design. It can be used as a form in the concept, or it can be reflected in the appropriate activities within the concept. Pragmatics is a meaningful phenomenon [46]. We can think of pragmatic fiction in design as a set of activities and a scenario showing a sequence of these activities. A space is not created solely by its existence. The activities within the space 
and those who use it literally exist. For this reason, the more activities provided in a space, the more open it is to use.

The research confirmed that the presented footbridge is absolutely necessary in accessing the Black Sea coast. In the near future, it is necessary to consider the construction of a new footbridge having a modified architectural form, because apart from its basic function, i.e., safety in pedestrian traffic, it should also meet an aesthetic function and confirm the cultural identity of the city. It should be considered to construct a footbridge of the 21st century using modern technologies and taking into account the tradition of the location.

\section{Conclusions}

The conducted research allowed answering the formulated research questions and putting forward the following conclusions:

1. The research was carried out in the city of Trabzon (Turkey) and covered the facility built in connection with the development of urbanization and as a result of more intense traffic on the transit road running along the Black Sea. It is possible to reach the seashore in the city mainly by crossing one of the seven footbridges over the Black Sea route. The footbridge that was the research subject, like others in this city, was built to ensure pedestrian safety and maintain the flow of transit traffic; however, modern architectural solutions should also take into account other functions of such construction, i.e., those expected by its users and also the ones discussed in the presented research.

2. The research revealed that the respondents under 25 used the overpass rarely (64\%); the percentage of such population over 25 was lower and amounted to $40 \%$. The percentage of people who frequently and daily used the overpass in the group under or 25 years of age was $12 \%$, whereas among older adults, it was $32 \%$. The differences are statistically significant $(p=0.027)$.

3. The respondents who chose the overpass for safety reasons usually used it rarely (59\%). Only 39\% of those who used the overpass every day or often selected safety as the reason. This means that as a pedestrian uses the overpass more frequently, he or she begins to notice other features of the overpass. The construction should also constitute an interesting element in terms of aesthetics or architectural solutions and harmonize with the environment.

4. Unfortunately, not all the respondents consider the pedestrian bridge over D010 safe. As many as $35.5 \%$ claimed it is not safe. It was therefore necessary to find a way to increase its safety. Recently, roofing has been installed along the entire length of the overpass, which has certainly increased its safety and protection against adverse weather conditions and noise, while at the same time reducing the incidents of throwing objects onto the highway.

5. Attracting public attention to the functionality and safety of using the overpass contributed, to some extent, to its modernization (roofing). However, it still leaves a lot to be desired in terms of limitations in pedestrian traffic (e.g., no elevator), architectural form and other functions it could perform in this environment.

6. When the Semantic Differential Scale was applied, the overpass did not receive a high positive score for the seven opposite adjectives. The overpass was found to be moderately "harmonious" and "safe", while very few found it "ugly", "unattractive", "ordinary" or "memorable". The "functional" score of 5.3 was considered as only "minimally functional". This situation shows that both the survey and the Semantic Differential Scale revealed the fact that this structure held no meaning.

7. When we think about the pedestrian bridge we will design, we need to create an activity sequence. First, the main task is the binding function, which must be provided in the best and safest way. The bridge should then include seating and rest areas. In addition, an area for observation and photography can be created on the bridge to encourage people in these activities. Seating areas can also be provided in this observation area. This makes it inviting to sit and gaze at the sea view and watch the 
movements of the sun. The semantic and functional aspects of Trabzon's largest and most crowded city square and Gazipaşa Avenue, an important street whose former value has been lost, are connected to the coast by this overpass.

8. The authors believe that the city authorities should aim at constructing a representative overpass, connecting the old part of the city with the Black Sea coast, which could also be a showcase of the city inhabited by 240,000 people and apart from the issue of safety could become a permanent element of its landscape as an attractive architectural object and a viewing point.

When the results of the study are evaluated in general, it is seen that the Imperial Overpass is safe, aesthetic and functional for Trabzon city and is used by different age groups to reach the coast. The results obtained through the questionnaires and observations confirm the hypotheses of the study. New activities can be created, and a new function can be given to the overpass in order to ensure that the footbridge can be used by everyone. Thus, the overpass gains a symbolic meaning for Trabzon city.

Supplementary Materials: The following are available online at https:/ / www.mdpi.com/article/10 .3390/land10040340/s1, Questionnaire S1.

Author Contributions: Conceptualization, S.S.K.K., H.G. and M.H.; methodology, H.G., S.S.K.K., M.H.; software, B.C.K.; B.P. and J.K.K.; validation, B.C.K. and B.P.; formal analysis, H.G.; investigation, M.H., S.S.K.K., B.C.K.; resources, B.P., M.H., J.K.K. and S.S.K.K.; data curation, H.G., S.S.K.K.; writingoriginal draft preparation, S.S.K.K., H.G., B.C.K., M.H. and B.P.; writing-review and editing, M.H., S.S.K.K., H.G., B.P. and J.K.K.; visualization, H.G., S.S.K.K. and M.H.; supervision, B.C.K.; project administration, M.H. and J.K.K.; funding acquisition, J.K.K. All authors have read and agreed to the published version of the manuscript.

Funding: This research was co-funded by the Wrocław University of Environmental and Life Sciences.

Institutional Review Board Statement: Not applicable.

Informed Consent Statement: Not applicable.

Data Availability Statement: Not applicable.

Conflicts of Interest: The authors declare no conflict of interest.

Limitations of the Study: One of the research aspects was to reveal a slightly different perception of the reality by the co-authors. The authors from Poland assess the current technical, functional and aesthetic condition of the footbridge more strictly, whereas the authors from Turkey are more focused on its reconstruction and modernization, approaching the footbridge as a permanent element of the city landscape. The research conducted in the footbridge area was accompanied by car noise, which made it difficult to interview the footbridge users.

\section{References}

1. Arslan Selçuk, S.; Er Akan, A. Bir Şehir İkonu Olma Yolunda Yaya Üst Geçitlerive Aydınlatmaları: ODTÜ Yaya ÜstGeçidiÖrneği. III. Ulusal Aydınlatma Sempozyumuve Sergisi Bildirileri Kitabı, Ankara, Turkey, 23-25 November 2005; pp. 37-43. Available online: http:/ / www.emo.org.tr/ekler/b2b4182156b2f1f_ek.pdf (accessed on 1 August 2019). (In Turkish).

2. Hasan, R.; Napiah, M. Utilization of footbridges: Influential factors and improvement proposals. Adv. Transp. Stud. Int. J. Sect. A 2017, 2017, 43.

3. Ribbens, H. Pedestrian facilities in South Africa: Research and practice. Transp. Res. Rec. J. Transp. Res. Board 1996, 1538, $10-18$. [CrossRef]

4. Kuşkun, P.A. Research on the Use of Outdoor Furniture in the Case of Erzurum. Erzurum Kent Bütününde Donatı Elemanlarının Kullanımı Üzerine Bir Araştırma. Master's Thesis, Institute of Natural and Applied Sciences, Atatürk University, Erzurum, Turkey, 2002. (In Turkish).

5. Keyvanfar, A.; Ferwati, M.S.; Shafaghat, A.; Lamit, H.A. Path Walkability Assessment Index Model for Evaluating and Facilitating Retail Walking Using Decision-Tree-Making (DTM) Method. Sustainability 2018, 10, 1035. [CrossRef]

6. Rahman, M.S.; Abdel-Aty, M.; Hasan, S.; Cai, Q. Applying Data Mining Techniques to Analyze the Pedestrian and Bicycle Crashes at the Macroscopic Level. In Proceedings of the Transportation Research Board 98th Annual Meeting, Washington, DC, USA, 13-17 October 2019; Available online: https:/ / trid.trb.org/view/1572936 (accessed on 27 July 2019).

7. Shaaban, K. Assessing Sidewalk and Corridor Walkability in Developing Countries. Sustainability 2019, 11, 3865. [CrossRef] 
8. Miśkiewicz, M.; Pyrzowski, Ł.; Okraszewska, R. Pedestrian and Bicycle Bridges as Examples of Safe Collision-Free Road Crossings. MATEC Web Conf. 2017, 122, 01005. Available online: https://www.matec-conferences.org/articles/matecconf/pdf/2017/36/ matecconf_gambit2017_01005.pdf (accessed on 13 July 2019). [CrossRef]

9. Bartoszewski, J.; Lessear, S. Tunele i Przejścia Podziemne w Miastach [Tunnels and Underground Passages in Cities]; WKŁ: Warszawa, Poland, 1979. (In Polish)

10. Nukta Ramadani, H.; Rahmani, H.; Gazali, A.A. Study of efficiency pedestrian bridge crossing in the road of Pangerang Antasari, Banjarmasin. In Proceedings of the MATEC Web of Conferences 181, Makassar, Indonesia, 4 November 2017; Available online: https:/ / www.matec-conferences.org/articles/matecconf/pdf/2018/40/matecconf_istsdc2017_06009.pdf (accessed on 13 July 2019). [CrossRef]

11. Binti Kadzim, H.N. Study on Effectiveness of Pedestrian Bridge Utilization. Bachelor's Thesis, Faculty of Civil Engineering \& Earth Resources University Malaysia Pahang, Pahang, Malaysia, 2012. Available online: http://umpir.ump.edu.my/id/eprint/ 14470/1/FKASA\%20-\%20NURUL\%20HIDAYAH\%20KADZIM.PDF (accessed on 4 August 2019).

12. Cohn, J.; Sperling, E. Improving Pedestrian and bicycle Connectivity During Rehabilitation of Existing Bridges. In Transportation Research Board; Pedestrian and Bicycle Information Center: Chapel Hill, NC, USA, 2016; pp. 1-13. Available online: http: //www.pedbikeinfo.org/cms/downloads/PBIC_WhitePaper_Bridges.pdf (accessed on 27 July 2019).

13. Biliszczuk, J.; Onysyk, J.; Prabucki, P.; Toczkiewicz, R. Kładki jako elementy infrastruktury zwiększające bezpieczeństwo pieszych [Footbridges as infrastructure elements increasing pedestrian safety]. Inżynieria I Bud. 2020, 6, 269-273. (In Polish)

14. North Seattle College. The Seattle Department of Transportation Northgate Pedestrian and Bicycle Bridge Alternative Development and Selection. Available online: https:/ /www.seattle.gov/Documents/Departments/SDOT/BridgeStairsProgram/ AlternativeDevelopmentandSelectionFINAL.pdf (accessed on 5 August 2019).

15. Altınçekiç, H.; Koç, H. Peyzaj Tasarımında Kent Mobilyalarıve Kalite Beklentileri. II. In Proceedings of the Uluslararası Kent Mobilyaları Sempozyumu, İstanbul, Turkey, 24-27 April 2003. (In Turkish).

16. Biliszczuk, J.; Machelski, C.; Onysyk, J.; Prabucki, P.; Węgrzyniak, M. Kładki dla pieszych jako punkty orientacyjne na autostradzie [Pedestrian bridges as landmarks on the highway]. Inżynieria I Bud. 2001, 11, 643-648. (In Polish)

17. Eyre, J. Aesthetics of Footbridge Design. In Proceedings of the International Conference on the Design and Dynamic Behaviour of Footbridges, Paris, France, 20-22 November 2002; pp. 96-103.

18. Idelberger, K. The World of Footbridges: From the Utilitarian to the Spectacular; Ernst \& Sohn: Berlin, Germany, 2011.

19. Flaga, K.; Januszkiewicz, K. On the aesthetic and technical efficiency of current arched footbridges. In Proceedings of the International Conference on the Design and Dynamic Behaviour of Footbridges, Wrocław, Poland, 6-8 July 2011 ; pp. 126-137.

20. Jamroz, K.; Gaca, S.; Michalski, L.; Kieć, M.; Budzyński, M.; Gumińska, L.; Kustra, W.; Mackun, T.; Oskarbska, L.; Rychlewska, J.; et al. Ochrona Pieszych. Podręcznik dla organizatorów ruchu pieszego. In Protection of Pedestrians. Guidelines for Pedestrian Traffic Organizer; National Road Safety Council: Gdansk, Poland; Warsaw, Poland; Cracow, Poland, 2014. (In Polish)

21. Ivan, K.; Benedek, J.; Ciobanu, S.M. School-Aged Pedestrian-Vehicle Crash Vulnerability. Sustainability 2019, 11, 1214. [CrossRef]

22. Congiu, T.; Sotgiu, G.; Castiglia, P.; Azara, A.; Piana, A.; Saderi, L.; Dettori, M. Built Environment Features and Pedestrian Accidents: An Italian Retrospective Study. Sustainability 2019, 11, 1064. [CrossRef]

23. Arroya, R.; Mars, L.; Ruiz, T. Perception of Pedestrian and Cyclist Environments, Travel Behaviors, and Social Networks. Sustainability 2018, 10, 3241. [CrossRef]

24. Gimsing, N. Cable Supported Bridges—Concept and Design; John Wiley and Sons: New York, NY, USA, 1997.

25. Flaga, A. Mosty Dla Pieszych [Pedestrian Bridges]; Wydawnictwa Komunikacji i Łacczności: Warszawa, Poland, 2011. (In Polish)

26. Keil, A. Pedestrian Bridges: Ramps, Walkways, Structures; Walter de Gruyter: Berlin, Germany, 2013.

27. Kasuga, A. Footbridge construction-A challenge for innovation and sustainability. In Proceedings of the International Conference on the Design and Dynamic Behaviour of Footbridges, London, UK, 16-18 July 2014; pp. 86-95.

28. Chen, W.; Duan, L. Handbook of International Bridge Engineering; Tylor \& Francis Group: New York, NY, USA, 2014.

29. Aksu, Ö. Yaya Üst Geçitlerinde Tasarım Ölçütlerinin İrdelenmesi. İstanbul Üniversitesi Orman Fakültesi Derg. 2014, 64, 12-28. [CrossRef]

30. Salamak, M.; Fross, K. Bridges in Urban Planning and Architectural Culture. Procedia Eng. 2016, 161, 207-212. [CrossRef]

31. Dietrich, R. Faszination Brücken; Callwey: München, Germany, 1998.

32. Demiroz, Y.I.; Onelcin, P.; Alver, Y. Illegal road crossing behavior of pedestrians at overpass locations: Factors affecting gap acceptance, crossing times and overpass use. Accid. Anal. Prev. 2015, 80, 220-228. [CrossRef]

33. Sinclair, M.; Zuidgeest, M. Investigations into pedestrian crossing choices on Cape Town freeways. Transp. Res. F 2016, 42, 479-494. [CrossRef]

34. Obeng-Atuah, D.; Poku-Boansi, M.; Cobbinah, P.B. Pedestrian crossing in urban Ghana: Safety implications. J. Transp. Health 2017, 5, 55-69. [CrossRef]

35. Anciaes, P.A.; Jones, P. Estimating preferences for different types of pedestrian crossing facilities. Transp. Res. Part F: Traffic Psychol. Behav. 2018, 52, 222-237. [CrossRef]

36. Banaś, A. Ocena komfortu pieszego na kładkach. Case study [Assessment of comfort on the footbridges. Case study]. Builder 2020, 8, 277. [CrossRef]

37. Cross, E.J.; Koo, K.Y.; Brownjohn, J.M.W.; Worden, K. Long-term monitoring and data analysis of the Tamar Bridge. Mech. Syst. Signal Process. 2013, 35, 16-34. [CrossRef] 
38. Lievens, K.; Lombaert, G.; De Roeck, G.; Van den Broeck, P. Robust design of a TMD for the vibration serviceability of a footbridge. Eng. Struct. 2016, 123, 408-418. [CrossRef]

39. Wang, D.; Wu, C.; Zhang, Y.; Li, S. Study on vertical vibration control of long-span steel footbridge with tuned mass dampers under pedestrian excitation. J. Constr. Steel Res. 2019, 154, 84-98. [CrossRef]

40. Matsumoto, Y.; Maeda, S.; Iwane, Y.; Iwata, Y. Factors affecting perception thresholds of vertical whole-body vibration in recumbent subjects: Gender and age of subjects, and vibration duration. J. Sound Vib. 2011, 330, 1810-1828. [CrossRef]

41. Mumcu, S. Investigation of Place Preferences in Open Spaces in Terms of Spatial Properties: The Case of Trabzon Atapark. AçıkMekânlardakiYerTercihlerinin, MekânsalÖzelliklerAçısındanİncelenmesi: Trabzon Atapark Örneği. Master's Thesis, Institute of Natural and Applied Sciences, Karadeniz Technical University, Trabzon, Turkey, 2002. (In Turkish).

42. Abojaradeh, M. Evaluation of Pedestrian Bridges and Pedestrian Safety in Jordan. Civil Environ. Res. 2013, 3, 66-78. Available online: https:/ / www.iiste.org/Journals/index.php/CER/article/view/3868/3927 (accessed on 3 August 2019).

43. Sharples, J.M.; Fletcher, J.P. Pedestrian Perceptions of Road Crossing Facilities Scottish Executive Central Research Unit, Edinburgh, United Kingdom. 2001. Available online: http:/ / www.gov.scot/resource/doc/156816/0042173.pdf (accessed on 11 July 2019).

44. James, E.; Millington, A.; Tomlinson, P.; Understanding community severance-Part 1: Views of practitioners and communities. Report to the UK Department for Transport, United Kingdom. 2005. Available online: http:/ / webarchive.nationalarchives.gov. uk/+/http:/www.dft.gov.uk/adobepdf/163944/Understanding_Community_Sev1.pdf (accessed on 11 July 2019).

45. Gür, Ş.Ö. Mekan Örgütlenmesi; Gür Yayıncılık: Trabzon, Turkey, 1996. (In Turkish)

46. Denli, S. The Analysis of Graphical Indication Meanings Regarding Semiology. Göstergebilim Açısından Grafik Gösterge Anlamlarının İncelenmesi. Master's Thesis, Institute of Social Sciences, Atatürk University, Erzurum, Turkey, 1997. (In Turkish). 